\title{
Knowledge and Attitude of Elderly regarding Assistive Devices; Explore Barriers
}

\section{Ahmed Mohamed Younis Mohamed ${ }^{1}$, Sharbat Thabiet Hassanen ${ }^{2}$, Abd el hamied Ibrahim Elsaid Mohamed elsheriny ${ }^{3}$, Eman Mohamed Elsherbeny ${ }^{4}$}

1. Bachelor of science in Nursing (BSN), faculty of Nursing Cairo university, Diploma in geriatric from National Institute of Longevity Elderly Schience, Beni suef -Egypt.

2. assistant Professor of community health Nursing, Faculty of Nursing, Fayoum University -Egypt 3. Assistant Professor of Physical Therapy for neuromuscular disorder and its surgery Department of Occupational therapy NILES, Beni-suef, Egypt, ORCID iD 0000-0001-7117-6976.

4. Lecturer of community health Nursing, Faculty of Nursing, Beni-suef University -Egypt.

E-mail address: Ahmed.younis3443@gmail.com

Telephone: 0097474036379

\begin{abstract}
Background: Assistive Device plays a significant role for improving elderly people independence and improve their quality of life. the current study Aimed to assess knowledge and attitude of elderly regarding assistive devices and explore barriers that affecting utilization of assistive devices among studied elderly people. Design: A descriptive research design was used in this study. Setting: The study was conducted was conducted at outpatient clinics in Beni-Suef university hospital. Sample: A convenient sample of (86) elderly people was recruited at the current study. Tools: Two tools were used I): A structured interviewing questionnaire which consisted of four parts to assess personal characteristics, medical history, effect of assistive devices on elderly quality of life, and knowledge of elderly people regarding assistive devices II): Scale to measure attitude of the elderly people regarding assistive devices. Results: the present study reveals that $50 \%$ of elderly people had ages ranged from $75 \geq 85$ yrs., $65.1 \%$ of them were male, $26.7 \%$ and $38.4 \%$ of the studied elderly people had inadequate knowledge and negative attitude respectively regarding assistive device. Conclusion: This study concluded that the majority of elderly people had inadequate knowledge and negative attitude toward the assistive device and a statistically significant relation between elderly people total attitude scores and their age, gender, marital status, and educational level, in addition a highly positive association between elderly people knowledge and attitude regrading assistive device. The study recommended that: Continuing educational programs regarding assistive devices should be provided for the elderly people to improve their knowledge and attitude.
\end{abstract}

Key words: Knowledge, Attitude, Elderly people, assistive devices, Barriers.

Submit Date : 1/12/2021

Accepted : 24/12/2021

Published : 1/1/2022 


\section{INTRODUCTION:}

Older age is characterized by the emergence of several complex health states that tend to occur only later in life which called geriatric syndrome (World health organization 2018). In these syndromes include like dementia, depression, delirium, incontinence, vertigo, falls, spontaneous bone fractures, failure to thrive, and neglect and abuse (1). During this stage health problem among them are common. There are various kinds of health problems experienced by the aged people. These include, visual impairments, hearing impairments, speech impairments, Physical disability, decline in word usage and vocabulary, pain in the joints, high or low blood pressure, falls and other illnesses (2). After they are not ambulatory and are dependent upon others so as to require care of their activities of daily living, such as eating, bathing, dressing, toileting and then they may get subjected to criminal and violent acts. Providing help and assistance to the individuals in meeting the daily requirements is typically cumbersome and tedious for members of the family and caregivers (3). although older individuals may live longer if they use assistive devices to improve their lives, many older adults use assistive devices (e.g., cane, walker, grab bar, or shower seat) or personal help to overcome limitations (4).

The term assistive devices " $r e f e r s$ to equipment and services that support and maintain the declined physical and cognitive functions due to age and disability (3). Assistive Devices (AD) means - any item, piece of equipment or product system, whether acquired commercially, modified or customized, that is used to increase, maintain, or improve functional capabilities of individuals with disabilities and elderly Such as; cane, wheelchairs, eyeglasses, hearing aids, communication devices etc. (5). In many low-income and middle-income countries, only 5-15\% of individual who require assistive devices and technologies have access to them(WHO).Mobility Assistive Equipment may be commonly used type of Assistive Technology Devices (ATD) to facilitate transfers, walking and wheeled mobility, and also the performance of mobility-related ADLs(6).Assistive technology plays significant role for increasing independence and facilitating physical restoration. Thus, improves quality of life for elderly people. A study by (Agree \& Freedman,2011) and (Molin et al. 2007) showed that the potential of assistive devices to support people with cognitive impairment to 
continue living at home and recommended that it is advantageous to develop and implement assistive devices for care of elderly people living at home (7).

Assistive technologies (ATs) can enable people with disabilities to live active, safe, productive, independent and dignified lives. There is a persistent demand, worldwide, for increased implementation of AT in community health services to meet the challenges posed by an ageing population and to facilitate active ageing and independent living. The enabling aspects of ATs and viewing them as tools for overcoming barriers to full participation, is a common understanding ( 8).

ISO 9999 defines assistive products as "any product (including devices, equipment, instruments, technology and software) especially produced or generally available". These assistive products refer to products that have been specifically designed for people with disabilities (e.g., wheelchairs, computer access technologies and environmental control systems) and or mainstream technology (e.g., simple devices such as nonslip mats and more complex devices such as smart home technologies) (9).

Assistive devices can play an important role to maintain or improve an individual's functioning and health to enable people to live at home independently and to improve participation in society,Assistive devices ranges from low-tech products, such as glasses or pill organizers to high-tech products, such as motorized wheelchairs or communication software. Assistive devices can benefit a wide range of people, including people with disabilities, the ageing population and people with non-communicable diseases (10).

According to Orem, naturally all humans can care for themselves and the focus of nursing should be identifying factors that hinders people from that and support in overcoming the limitations and enable people to attain self-care. when individuals need care that is greater than their current ability, self-care disability occurs (11).

Health care professionals, informal caregivers, family, and friends play vital role in supporting self-care of older individuals. Care givers needs to provide psychological and physical support to motivate older people to have initiation for self-care and be able to actualize self-care activity. Older people with illnesses and diseases may easily lose their motivation to provide self-care. They need support from care givers to identify and prevent self-deception (12). 
Nurses have a pivotal role and responsibilities in supporting self-care includes assessing abilities of people to provide caring for own selves and identifying limitations that affects self-care abilities. Nurses also involve in selecting assistive devices services and devices that supports individuals in their disabilities and help them to attain self-care (13).

\section{Significance of the study}

Globally, the population aged 65 and over is growing faster than all other age groups. (United nation 2020). By 2050, the world 's population aged 60 years and older is predicted to succeed in a complete of 2 billion, up from 900 million in 2015. Today, 125 million people are aged 80 years or older (World health organization, 2018). In keeping with data from World Population Prospects: the 2019 Revision, by 2050 , one in six people within the world are going to be over age $65(16 \%)$, up from one in 11 in 2019 (9\%) (United Nations Population Fund 2017) By 2050, 80\% of all older people will live in low-and middle-income countries (14).

The growing numbers of elderly people are expected to lead to an increasing demand for assistive devices. The purpose of this study was to examine changes in the use of assistive devices over time and their relation to dependence in daily activities among old persons living at home, having difficulty performing basic selfcare, mobility activities and activities of daily living is common in late life. In 2011, more than one quarter of community-dwelling older adults reported limitation in performing one or more self-care or mobility activities. The most prevalent limitation is walking, followed by getting out of bed or a chair, bathing or showering, dressing, using the toilet, and eating (15).

Well-being is a multidimensional concept Prior studies have shown that selfcare and mobility limitations are related to several dimensions of well-being. Specifically, such limitations often decrease older adults' positive affect and selfrealization_by restricting their social participation. Limitations in self-care and mobility activities also prevent older adults from performing everyday routines on their own and subsequently decrease their sense of self-efficacy (16). 


\section{Subjects and Methods:}

\section{Aims of this study: -}

The aims of this study to assess knowledge and attitude of elderly regarding assistive devices and explore barriers that affecting utilization of assistive devices among studied elderly people.

\section{Research questions}

In order to address the purpose of the study, the following study question was formulated:

1. What is the level of elderly people's knowledge regarding assistive devices?

2. What is the level of elderly people's attitudes regarding assistive devices?

3. What are the barriers affecting utilization of assistive devices among elderly people studied?

The following four designs were used to discuss the current study's subject and methods:

- Technical Design

- Operational Design

- Administrative Design

1. Statistical Design

\section{Technical Design:}

The study's technical design includes research design, a study environment, study participants, and data collection instruments.

\section{Research design:}

To fulfill the present study's goals, a descriptive research approach was used. 


\section{Settings:}

The current study was conducted at outpatient clinics at Beni-Suef university hospital. These clinics provide multispecialty health services and cover all BeniSuef citizens.

\section{Subjects:}

A convenience sample of all elderly people (86) who attended the outpatient clinics at Beni-Suef university hospital and agreed to participate in the study.

\section{Tools of data collection:}

Two tools were designed to collect data:

\section{Tool (I): Interviewing questionnaire sheet}

This tool was created by a researcher after analyzing relevant national and international literature. It is divided into four sections:

\section{Part I: Socio-demographic features}

This part aimed to collect data about elderly people's socio-demographic characteristics, including age, gender, educational level, marital status, monthly income, etc.

\section{Part II: Medical history for elderly people:}

This part aimed to collect medical data about elderly people, including current home treatment, number of currently used medications, level of dependency in performing activities of daily living, etc.

\section{Part III: Effect of assistive devices on elderly people's quality of life:}

This part aimed to evaluate the effect of assistive devices on elderly people's quality of life through providing a main four questions regarding the different quality of life 
domains (physical, social, emotional, and daily activities), and each elderly person was asked to give the effect of the device on quality of life a score from (0-10). The total score was calculated as: (0. No effect, 1-3 slightly affected, 4-7 moderately affected, 8-10 highly affected).

\section{Part IV: elderly people's knowledge questionnaire sheet}

This part aimed to collect data about elderly people's knowledge of assistive devices. The study consists of five main assistive device-related questions (e.g., definition and purpose of assistive devices), each of which has a number of correct answers. The elderly people who were studied were asked to choose the correct answer, and they were informed that they could choose more than one answer.

\section{Scoring system:}

Elderly people's knowledge was tested by being asked to choose if the given answers were correct or incorrect, and elderly responses were scored as 1 and 0 respectively. The scores of the items were summed up and the total was divided by the number of items. These scores were converted into percent scores.

Total scores of elderly people's knowledge were considered.

Satisfactory---------total percent score is $60 \%$ of total knowledge score. Unsatisfactory---------total percent score is $60 \%$ of total knowledge score.

\section{Tool (2): : Elderly people's attitudes toward assistive devices}

A three-point Likert scale was used to evaluate the elderly people's attitude toward assistive devices; it consists of 15 items.

I'm reviewing with physiotherapy/OT to ensure the safety of using assistive devices," I believe I'm using assistive devices as the therapist explains," I believe I should check for safety before using an assistive device," and so on. 


\section{Scoring system:}

The elderly patients' responses were in the form of a three-point Likert scale, which ranged from "agree," "uncertain, and "disagree," and the elderly people's scores were scored as 2, 1, and 0 respectively. The scores of the items were summed up and the total divided by the number of items. These scores were converted into percent scores. Total scores of elderly people's attitudes were calculated as:

positive attitude------ The total percent score is $60 \%$ of the total attitude score.

Negative attitude------total percent score is $60 \%$ of total knowledge score.

\section{Tools Validity:}

The validity of the research instruments was evaluated A panel of five Faculty members of community health nursing and medical surgical nursing department reviewed the previous tools. Members of the jury group evaluated the study aids based on their comprehensiveness, correctness, and linguistic clarity. Some elements were corrected, added, and/or omitted based on their recommendations.

\section{Dependability:}

Cronbach's alpha was used to assess the research tool's internal consistency. It was 0.762 for the research tool.

\section{II: Operational Design:}

This research's operational design consisted of three phases: preparation, pilot study, and field work.

\section{Preparatory phase}

This phase began with a survey of current and previous national and worldwide relevant literature on the themes of study, including textbooks, papers, journals, and websites. This evaluation was useful in assessing and constructing data collection tools, and the investigator then verified the tool's validity using a jury of experts to examine the substance, knowledge, accuracy, and relevance of questions for tools. 


\section{Pilot study:}

A pilot study was conducted on $10 \%$ of the entire study sample ( 9 participants) to test the applicability, efficiency, clarity of tools, the evaluation of field work feasibility, and to discover any potential hurdles that could confront the investigator and interfere with data collection. Based on the outcomes of the pilot research, necessary adjustments were made, such as the omission of certain questions from the tool in order to reinforce their content or for greater simplicity and clarity. The pilot research sample was not included in the main study sample.

\section{Fieldwork}

The study's data collection took four months. The study's data gathering began in early December 2020 and will be finished by the end of March 2021. The researcher visited the outpatient clinics at Beni-Suef University Hospital. For the elderly, three days a week from 9 a.m. to 2 p.m.

The investigator initially described the goal of the study to the older individuals and assured them that the information gathered would be kept secret and utilized exclusively for the purpose of the research. At Beni-Suef University Hospital, the investigator met with elderly people. Senior adults completed tools regarding people's knowledge and attitudes about assistive technologies, and each elderly patient spent between 30 and 45 minutes completing an interview questionnaire sheet.

\section{Administrative Design.}

The dean of the school of nursing at Beni-Suef University addressed an official letter asking for authorization to conduct the research to Beni-Suef University hospital in order to secure their clearance to carry out this study. This letter contained the purpose of the research as well as photocopies of data collection instruments in order to get permission and assistance with data collection. 


\section{Ethical Consideration}

Prior to the start of the study, the scientific research ethics committee of Beni-Suef University's faculty of nursing acquired ethical permission. The researcher met with the director of Beni-Suef University Hospital to describe the study's purpose and get their agreement. The researcher also visited with older people to explain the goal of the study and seek their permission to participate. They were reassured that the acquired data was anonymous and private, and that it would only be used for scientific study. The participants were guaranteed the ability to withdraw from the research at any time.

\section{IV: Statistical Analysis:}

The acquired data was coded and loaded into the social science statistical software (SPSS 26.0). Data was given, and appropriate analysis was performed based on the kind of data gathered for each parameter. For categorical variables, data was presented using descriptive statistics in the form of frequencies and percentages. The Chi-square (X2) test was used to compare qualitative categorical variables, but where the predicted count was less than 5 in more than $20 \%$ of the cells, Person and Spearman correlation was employed to investigate the correlation between quantitative variables. Statistical significance was evaluated when the P-value was less than 0.05 . 


\section{RESULTS:}

\section{Part I: Demographic characteristics of the elderly people}

Table (1) Percentage distribution of demographic characteristics of elderly people $(\mathrm{n}=86$ people).

\begin{tabular}{|l|c|c|}
\hline \multicolumn{1}{|c|}{ Demographic characteristics } & No & $\%$ \\
\hline Age & & \\
\hline $65 \geq 75$ yrs. & 37 & 43 \\
\hline $75 \geq 85$ yrs. & 43 & 50 \\
\hline$\geq 85$ yrs. & \multicolumn{2}{|c|}{$76.58 \pm 4.85$} \\
\hline Mean \pm SD & \multicolumn{2}{|c|}{} \\
\hline Gender & 56 & 65.1 \\
\hline Male & 30 & 34.9 \\
\hline Female & & \\
\hline Marital status & 34 & 39.5 \\
\hline Married & 8 & 9.3 \\
\hline Single & 7 & 8.1 \\
\hline Divorced & 37 & 43 \\
\hline Widowed & & \\
\hline Educational level & 12 & 14. \\
\hline Illiterate & 24 & 27.9 \\
\hline Read and write & 17 & 19.8 \\
\hline Secondary school & 20 & 23.3 \\
\hline Technical school & 13 & 15.1 \\
\hline University and above & & \\
\hline Monthly income & 46 & 53.5 \\
\hline Enough & 40 & 46.5 \\
\hline Not enough & & \\
\hline Job & 24 & 27.9 \\
\hline Governmental sector & 15 & 17.4 \\
\hline Private sector & 14 & 16.3 \\
\hline Freelancers & 17 & 18.6 \\
\hline Crafts & 17 & 19.8 \\
\hline Not working & & 7 \\
\hline Tabl: & & \\
\hline
\end{tabular}

Table 1: shows that $50 \%$ of elderly people had ages ranged from $75 \geq 85$ yrs., $65.1 \%$ of them were male. $43 \% \& 39.5 \%$ of elderly people were widowed and married respectively. $27.9 \%$ of elderly people could read and write. $53.5 \%$ of 
elderly people had enough monthly income. $27.9 \%$ of elderly people had job in governmental sector.

Part II: Medical history of the elderly people

Table (2) Percentage distribution of the medical history of elderly people $(n=86$ people).

\begin{tabular}{||l|c|c|}
\hline \multicolumn{1}{|c|}{ Medical history } & No & \% \\
\hline Asthma & 40 & 46.5 \\
\hline Diabetes mellitus & 65 & 75.6 \\
\hline Chronic renal disease & 16 & 23.3 \\
\hline Liver disease & 8 & 9.3 \\
\hline Cardiac disease & 7 & 8.1 \\
\hline Glaucoma & 2 & 2.3 \\
\hline Hypertension & 60 & 69.8 \\
\hline Tumor & 4 & 4.7 \\
\hline Autoimmune disorder & 11 & 12.8 \\
\hline GI disturbances & 15 & 17.4 \\
\hline Chronic obstructive pulmonary disease (COPD) & 10 & 11.6 \\
\hline Skin disorders & 11 & 12.8 \\
\hline
\end{tabular}

Table 2: reveals that the highest percentages $75.6 \%, 69.8 \%$ and $46.5 \%$ of the studied elderly people had diabetes mellitus, hypertension, and asthma respectively. Table (3) Percentage distribution of the medical history of elderly people ( $\mathrm{n}=86$ people).

\begin{tabular}{|l|c|c|}
\hline \multicolumn{1}{|c|}{ Medical history } & No & \% \\
\hline Number of currently used medications & & \\
\hline - Less than 5 medications & 49 & 57 \\
\hline - More than 5 medications & 37 & 43 \\
\hline Level of dependency in performing Activity of Daily Living & & \\
\hline - Independent & 29 & 33.7 \\
\hline - partially dependent & 40 & 46.5 \\
\hline - Totally dependent & 17 & 19.8 \\
\hline Current living situation & & \\
\hline - Home with family & 55 & 63.9 \\
\hline - Home with caregiver & 26 & 30.2 \\
\hline - Home independently & 5 & 5.8 \\
\hline Accessibility to medical health services & & \\
\hline - Easy to reach & 38 & 44.2 \\
\hline - Difficult to reach & 48 & 55.8 \\
\hline
\end{tabular}


Table 3: illustrates that $57 \%$ of elderly people used less than 5 medications. $46.5 \%$ of elderly people were partial dependent to perform activity of daily living. $63.9 \%$ of elderly people were lived in home with family. $55.8 \%$ of elderly people had difficult to reach to medical health services.

Table (4): distribution of assistive devices using history among studied elderly people

\begin{tabular}{|l|c|c|}
\hline \multicolumn{1}{|c|}{ Variable } & No & $\%$ \\
\hline Onset of using assistive device & & \\
\hline $1-<5$ years & 22 & 25.6 \\
\hline $5-<10$ years & 30 & 34.9 \\
\hline$\geq 10$ years & 34 & 39.5 \\
\hline Number of utilized assistive device & 14 & 16.3 \\
\hline One & 45 & 52.3 \\
\hline Two & 27 & 31.4 \\
\hline Three & & \\
\hline Previous training regarding assistive devices & 44 & 51.2 \\
\hline Yes & 42 & 48.8 \\
\hline No & & \\
\hline $\begin{array}{l}\text { Regular check and maintenance of assistive } \\
\text { device }\end{array}$ & 40 & 46.5 \\
\hline Yes & 46 & 53.5 \\
\hline No & & \\
\hline
\end{tabular}

Table (4): indicates that $39.5 \%$ of the studied elderly people utilized the assistive devices from more than 10 years ago.52.3\%, 31.4\% of them utilized two and three assistive devices. Furthermore $53.5 \%$ of them don't check and maintain assistive device regularly.

Table (5): distribution of effect of assistive devices on quality of life among studied elderly people

\begin{tabular}{|l|l|l|l|l|l|l|}
\hline \multirow{2}{*}{ Variable } & \multicolumn{2}{|l|}{$\begin{array}{l}\text { Highly } \\
\text { affected }\end{array}$} & \multicolumn{2}{l|}{$\begin{array}{l}\text { Moderately } \\
\text { affected }\end{array}$} & \multicolumn{2}{l|}{$\begin{array}{l}\text { Slightly } \\
\text { affected }\end{array}$} \\
\cline { 2 - 8 } & No & $\%$ & No & $\%$ & No & $\%$ \\
\hline Physical wellbeing & 36 & 41.9 & 30 & 34.9 & 20 & 23.2 \\
\hline Social wellbeing & 36 & 41.9 & 31 & 36.0 & 19 & 22.1 \\
\hline Emotional wellbeing & 24 & 27.9 & 43 & 50.0 & 19 & 22.1 \\
\hline Daily activities & 26 & 30.2 & 49 & 57.0 & 11 & 12.8 \\
\hline Self-care abilities & 44 & 51.1 & 32 & 37.2 & 10 & 11.7 \\
\hline
\end{tabular}


Table (5): reveals that $51.1 \%$ \& $41.9 \%$ and $41.9 \%$ of the studied elderly people reported that utilizing assistive devices improve their self-care abilities, physical wellbeing and social wellbeing respectively. On the other hand, 57.0\% and $50.0 \%$ of them reported that utilizing assistive devices moderately affected their daily activities and emotional wellbeing.

\section{Part III: Elderly people' knowledge regarding assistive devices}

Table (6) Percentage distribution of elderly people' knowledge about assistive devices definition and purpose of using assistive devices ( $n=86)$.

\begin{tabular}{||l|c|l|l|l||}
\hline \multicolumn{1}{|c|}{ Knowledge } & \multicolumn{2}{c|}{ Correct } & \multicolumn{2}{l|}{ Incorrect } \\
\hline Definition of assistive device & No & $\%$ & No & $\%$ \\
\hline $\begin{array}{l}\text { a term covering the systems and services related to the delivery of assistive } \\
\text { products and services }\end{array}$ & 7 & 8.1 & 79 & 91.9 \\
\hline Purpose of using assistive device & & & & \\
\hline Maintain elderly people independence & 4 & 4.7 & 82 & 95.3 \\
\hline Promoting elderly people well-being. & 9 & 10.5 & 77 & 89.5 \\
\hline Maintain elderly people functioning & 48 & 55.8 & 38 & 44.2 \\
\hline
\end{tabular}

Table (6): reveals that $91.9 \% \& 95.3 \%$ of the studied elderly people reported incorrect answer regarding the definition of assistive device and that the purpose of using assistive device was to maintain elderly people independence. On the other hand, 55.8\% of them had correct answer regarding that the purpose of using assistive device was to maintain elderly people functioning.

Table (7) Percentage distribution of elderly people' knowledge about the people who can use assistive devices $(n=86)$.

\begin{tabular}{|l|c|c|c|c|}
\hline \multicolumn{1}{|c|}{ Knowledge } & \multicolumn{2}{c|}{ Correct } & \multicolumn{2}{l|}{ Incorrect } \\
\hline \multicolumn{1}{|c|}{} & $\mathrm{NO}$ & $\%$ & $\mathrm{NO}$ & $\%$ \\
\hline People with disabilities & 72 & 83.7 & 14 & 16.3 \\
\hline Elderly people & 8 & 9.3 & 78 & 90.7 \\
\hline $\begin{array}{l}\text { People with non-communicable diseases such as diabetes and } \\
\text { stroke }\end{array}$ & 11 & 12.8 & 75 & 87.2 \\
\hline $\begin{array}{l}\text { People with mental health conditions including dementia and } \\
\text { autism }\end{array}$ & 10 & 11.6 & 76 & 88.4 \\
\hline People with gradual functional decline & 39 & 45.3 & 47 & 54.7 \\
\hline
\end{tabular}


Table (7): shows that $90.7 \% \& 87.2 \%$ of the studied elderly people reported incorrect answer regarding that elderly people and People with non-communicable diseases such as diabetes and stroke are the types of people who using assistive devices. On the other hand, $45.3 \%$ of them had a correct answer regarding that People with gradual functional decline.

Table (8) Percentage distribution of elderly people' knowledge about assistive devices $(n=86$ people).

\begin{tabular}{||l|c|c|c|c|}
\hline \multicolumn{1}{|c|}{ Knowledge } & \multicolumn{2}{c|}{ Correct } & \multicolumn{2}{c|}{ Incorrect } \\
\hline Care of assistive device & NO & $\%$ & NO & $\%$ \\
\hline Regular check & 6 & 7.0 & 80 & 93 \\
\hline Daily care & 42 & 48.8 & 44 & 51.1 \\
\hline Apply assistive device care instruction & 14 & 16.3 & 72 & 83.7 \\
\hline Types of assistive device & & & & \\
\hline Mobility assistive device & 39 & 45.3 & 47 & 54.6 \\
\hline Hearing assistive device & 9 & 10.5 & 77 & 89.5 \\
\hline Cognitive assistive device & 48 & 55.8 & 38 & 44.2 \\
\hline Eating assistive device & 6 & 7.0 & 80 & 93 \\
\hline
\end{tabular}

Table (8): clarifies that the highest percentages $93.0 \%$, of the studied elderly people reported incorrect answers regarding that care of assistive devices should be done regularly, also had incorrect answer regarding that eating assistive devices is a type of assistive devices. On the other hand, 55.8\% \&48.8\% had a correct knowledge regarding cognitive assistive device as a type of assistive device and the daily care for assistive devices.

Table (9) Percentage distribution of total knowledge scores of elderly people ( $\mathrm{n}=86$ people).

\begin{tabular}{||l|c|c|}
\hline \multirow{2}{*}{ Total knowledge } & \multicolumn{2}{c|}{ Total knowledge scores } \\
\cline { 2 - 3 } & No & \% \\
\hline Adequate knowledge & 23 & 26.7 \\
\hline Inadequate knowledge & 63 & 73.3 \\
\hline
\end{tabular}

Table (9): illustrates that $73.3 \%$ of the studied elderly people had inadequate level of total knowledge regarding the assistive devices. 


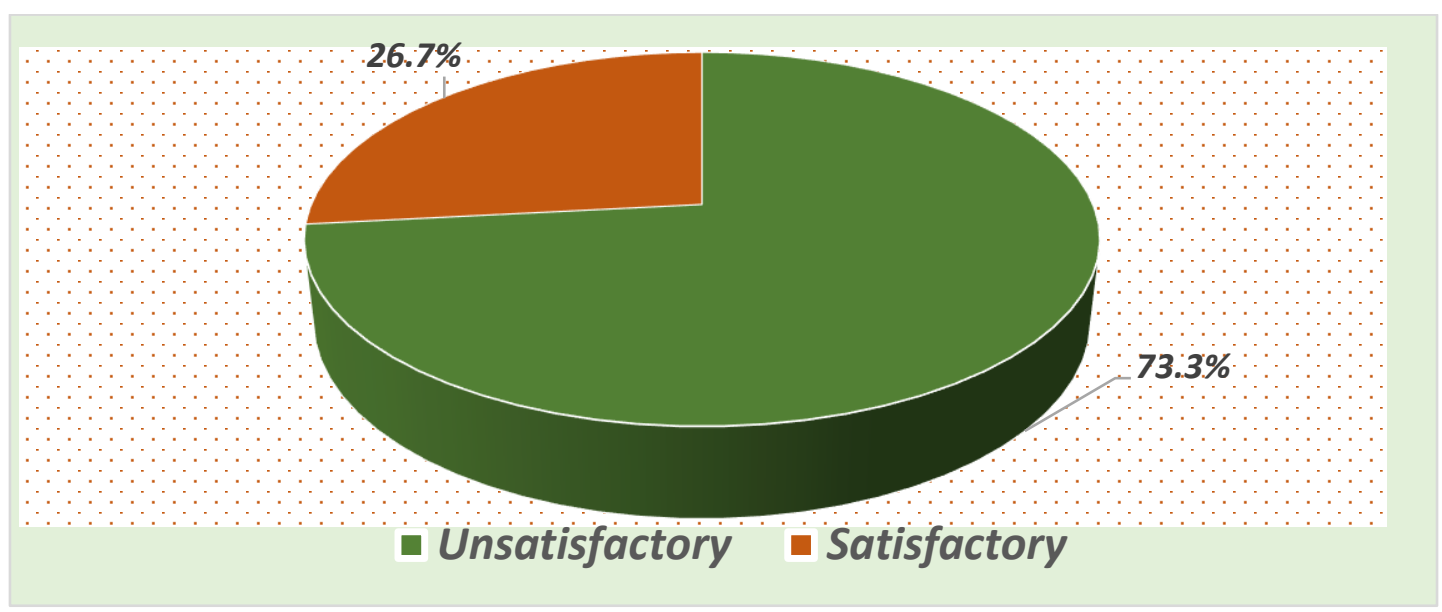

Figure (1) Percentage distribution of total knowledge scores of elderly people ( $\mathrm{n}=86$ people).

\section{Part IV: Elderly people' attitude toward assistive devices.}

Table (10) Percentage distribution of elderly people' attitude toward assistive devices $(n=86$ people).

\begin{tabular}{|c|c|c|c|c|c|c|}
\hline \multirow[t]{2}{*}{ Assistive devices attitude items } & \multicolumn{2}{|c|}{ Agree } & \multicolumn{2}{|c|}{ Sometimes } & \multicolumn{2}{|c|}{ Disagree } \\
\hline & No & $\%$ & No & $\%$ & No & $\%$ \\
\hline Using assistive devices reduce stress on family careers & 9 & 10.5 & 53 & 61.6 & 24 & 27.9 \\
\hline Utilizing assistive device should be as therapists explain. & 13 & 15.1 & 45 & 52.3 & 28 & 32.6 \\
\hline $\begin{array}{l}\text { It is important to check for safely using of assistive device } \\
\text { before using. }\end{array}$ & 11 & 12.8 & 48 & 55.8 & 27 & 31.4 \\
\hline using assistive device should be under supervision & 14 & 16.3 & 52 & 60.5 & 20 & 23.3 \\
\hline Assistive device enables me to manage daily activities. & 16 & 18.6 & 46 & 53.5 & 24 & 27.9 \\
\hline Using assistive devices is important role in my social life. & 17 & 19.8 & 43 & 50.0 & 26 & 30.2 \\
\hline I'm able to use assistive device independently. & 22 & 25.6 & 30 & 34.9 & 34 & 39.5 \\
\hline $\begin{array}{l}\text { It is important to ensure efficiency of assistive device before } \\
\text { using. }\end{array}$ & 27 & 31.4 & 45 & 52.3 & 14 & 16.3 \\
\hline Using assistive device increases my self confidence & 25 & 29.1 & 25 & 29.1 & 36 & 41.9 \\
\hline Using assistive device properly prevent incidents of falls. & 18 & 20.9 & 38 & 44.2 & 30 & 34.9 \\
\hline Assistive devices should be safe & 29 & 33.7 & 36 & 41.9 & 21 & 24.4 \\
\hline Using assistive device can improve my quality of life & 28 & 32.6 & 41 & 47.7 & 17 & 19.8 \\
\hline Using assistive device supports a sense of self dignity & 19 & 22.1 & 47 & 54.7 & 20 & 23.3 \\
\hline Using assistive devices promote my self-care abilities. & 14 & 16.3 & 52 & 60.5 & 20 & 23.3 \\
\hline Assistive devices can reduce home care costs for older adults & 29 & 33.7 & 36 & 41.9 & 21 & 24.4 \\
\hline
\end{tabular}


Table (10): clarifies that the highest percentages of elderly people $(41.9 \%$ \& $39.5 \%$ ) of the elderly people disagreed that using assistive device increases my selfconfidence and they are able to use assistive device independently respectively. In addition, $61.6 \% \& 60.5 \%$ of the studied elderly people were uncertain regarding that using assistive devices reduce stress on family careers and should be under supervision. On the other hand, 33.7\%, 33.7\% and 32.6\% of them were agreed regarding that Assistive devices should be safe, reduce home care costs for older adults and improve quality of life respectively.

Table (11) Percentage distribution of total attitude scores of elderly people $(n=86$ people).

\begin{tabular}{|l|c|c|}
\hline \multirow{2}{*}{ Total attitude score } & \multicolumn{2}{|c|}{ Total attitude scores } \\
\cline { 2 - 3 } & No & \% \\
\hline Positive attitude & 33 & 38.4 \\
\hline Negative attitude & 53 & 61.6 \\
\hline
\end{tabular}

Table (11): illustrates that $61.6 \%$ of the studied elderly people had a negative attitude regarding the assistive devices.

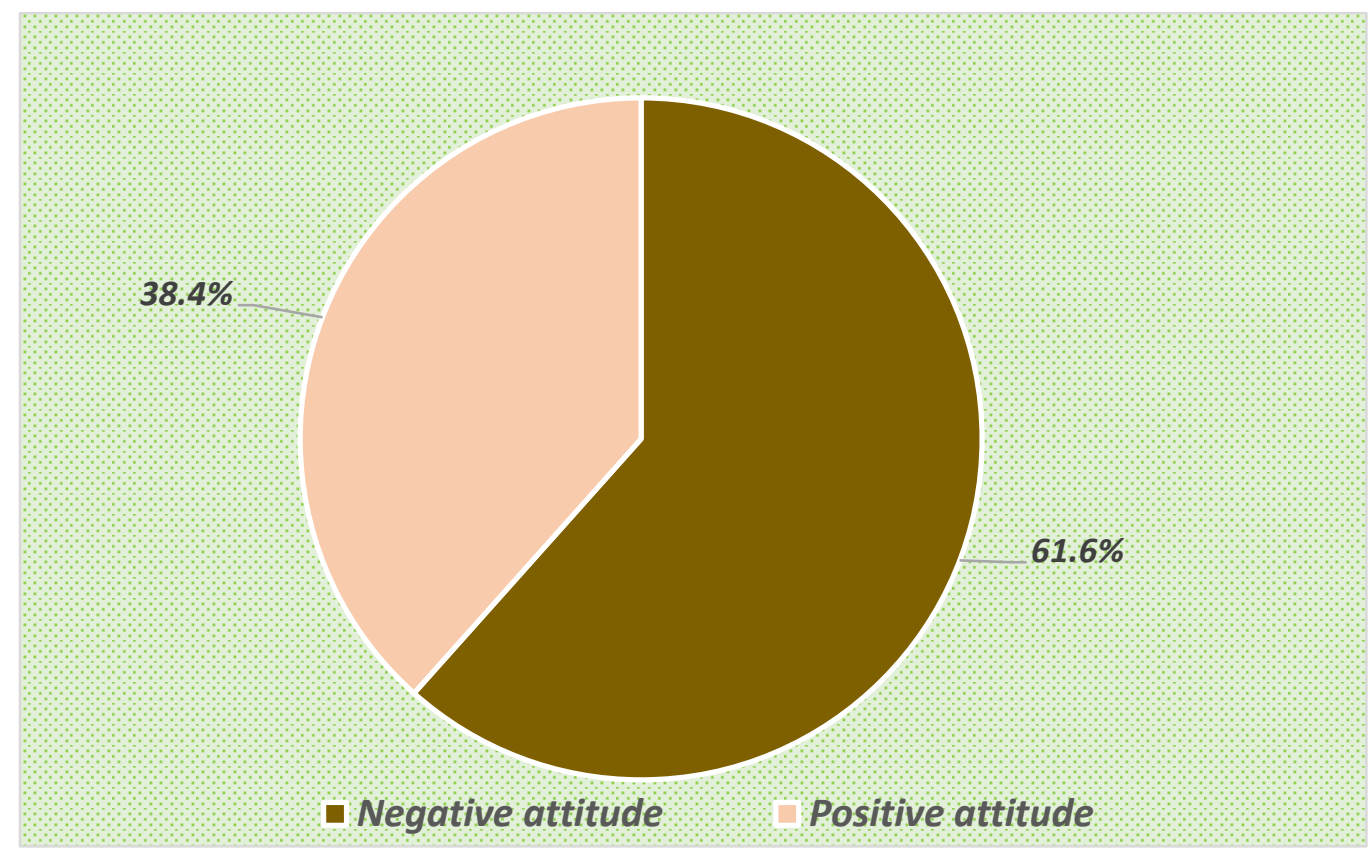

Figure (2) Percentage distribution of total attitude scores of elderly people ( $n=86$ people). 


\section{Part V: Relations and correlations between the study variables}

Table (12) the relation between elderly people' demographic characteristics and their total knowledge scores

\begin{tabular}{|c|c|c|c|c|c|c|c|}
\hline \multirow[t]{2}{*}{$\begin{array}{l}\text { Demographic } \\
\text { characteristics }\end{array}$} & \multirow[t]{2}{*}{ No } & \multicolumn{2}{|c|}{$\begin{array}{c}\text { Unsatisfactory } \\
\text { knowledge }\end{array}$} & \multicolumn{2}{|c|}{$\begin{array}{c}\text { Satisfactory } \\
\text { knowledge }\end{array}$} & \multirow[t]{2}{*}{$\mathrm{X}^{2}$} & \multirow[t]{2}{*}{ P-Value } \\
\hline & & No & $\%$ & No & $\%$ & & \\
\hline \multicolumn{6}{|l|}{ Age } & \multirow{4}{*}{3.78} & \multirow{4}{*}{$.042 *$} \\
\hline - 65-<75 yrs. & 37 & 13 & 15.1 & 24 & 27.9 & & \\
\hline$-75-<85$ yrs. & 43 & 10 & 11.6 & 33 & 38.4 & & \\
\hline$-\geq 85$ yrs. & 6 & 0 & 0 & 6 & 7.0 & & \\
\hline \multicolumn{6}{|l|}{ Gender } & \multirow{3}{*}{2.31} & \multirow{3}{*}{.104} \\
\hline - Male & 56 & 12 & 14.0 & 44 & 51.2 & & \\
\hline - Female & 30 & 11 & 12.8 & 19 & 22.1 & & \\
\hline \multicolumn{6}{|l|}{ Marital status } & \multirow{5}{*}{22.4} & \multirow{5}{*}{$.000 * *$} \\
\hline - Married & 34 & 9 & 10.5 & 25 & 29.1 & & \\
\hline - Single & 8 & 2 & 2.3 & 6 & 7.0 & & \\
\hline - Divorced & 7 & 7 & 8.1 & 0 & 0 & & \\
\hline - Widowed & 37 & 5 & 5.8 & 32 & 37.2 & & \\
\hline \multicolumn{6}{|l|}{ Educational level } & \multirow{6}{*}{8.62} & \multirow{6}{*}{$.019 *$} \\
\hline - Illiterate & 12 & 2 & 2.3 & 10 & 11.6 & & \\
\hline - Read and write & 24 & 9 & 10.5 & 15 & 17.4 & & \\
\hline - Secondary school & 17 & 7 & 8.1 & 10 & 11.6 & & \\
\hline - Technical school & 20 & 5 & 5.8 & 15 & 17.4 & & \\
\hline - University and above & 13 & 0 & 0 & 13 & 15.1 & & \\
\hline \multicolumn{6}{|l|}{ Monthly income } & \multirow{3}{*}{14.8} & \multirow{3}{*}{$.000 * *$} \\
\hline - Enough & 46 & 5 & 5.8 & 41 & 47.7 & & \\
\hline - Not enough & 40 & 18 & 20.9 & 22 & 25.6 & & \\
\hline \multicolumn{6}{|l|}{ Job } & \multirow{6}{*}{23.9} & \multirow{6}{*}{$.000 * *$} \\
\hline - Governmental sector & 24 & 0 & 0 & 24 & 27.9 & & \\
\hline Private sector & 15 & 5 & 5.8 & 10 & 11.6 & & \\
\hline - Freelancers & 14 & 10 & 11.6 & 4 & 4.7 & & \\
\hline - Crafts & 16 & 3 & 3.5 & 13 & 15.1 & & \\
\hline - Not working & 17 & 5 & 5.8 & 12 & 14.0 & & \\
\hline
\end{tabular}


Table (12): reveals that there is a highly statistically significant relation between elderly people total knowledge scores and their marital status, monthly income, and job. Also, there is a statistically significant relation between elderly people total knowledge scores and their age and educational level. While, there is no statistically significant relation between elderly people total knowledge scores and their gender. Table (13) the relation between elderly people' demographic characteristics and their total attitude scores

\begin{tabular}{|c|c|c|c|c|c|c|c|}
\hline \multirow[t]{2}{*}{ Demographic characteristics } & \multirow[t]{2}{*}{ No } & \multicolumn{2}{|c|}{$\begin{array}{l}\text { Negative } \\
\text { attitude }\end{array}$} & \multicolumn{2}{|c|}{$\begin{array}{l}\text { Positive } \\
\text { attitude }\end{array}$} & \multirow[t]{2}{*}{$\mathbf{X}^{2}$} & \multirow[t]{2}{*}{$\begin{array}{c}\text { P- } \\
\text { Value }\end{array}$} \\
\hline & & No & $\%$ & No & $\%$ & & \\
\hline \multicolumn{6}{|l|}{ Age } & \multirow{4}{*}{4.13} & \multirow{4}{*}{$.042 *$} \\
\hline$-65-<75$ yrs. & 37 & 21 & 24.4 & 16 & 18.6 & & \\
\hline$-75-<85$ yrs. & 43 & 26 & 30.2 & 17 & 19.8 & & \\
\hline$-\geq 85$ yrs. & 6 & 6 & 7.0 & 0 & 0 & & \\
\hline \multicolumn{6}{|l|}{ Gender } & \multirow{3}{*}{6.52} & \multirow{3}{*}{$.011^{*}$} \\
\hline - Male & 56 & 40 & 46.5 & 16 & 18.6 & & \\
\hline - Female & 30 & 13 & 15.1 & 17 & 19.8 & & \\
\hline \multicolumn{6}{|l|}{ Marital status } & \multirow{5}{*}{5.81} & \multirow{5}{*}{$.027^{*}$} \\
\hline - Married & 34 & 19 & 22.1 & 15 & 17.4 & & \\
\hline - Single & 8 & 6 & 7.0 & 2 & 2.3 & & \\
\hline - Divorced & 7 & 7 & 8.1 & 0 & 0 & & \\
\hline - Widowed & 37 & 21 & 24.4 & 16 & 18.6 & & \\
\hline \multicolumn{6}{|l|}{ Educational level } & \multirow{6}{*}{6.71} & \multirow{6}{*}{$.036^{*}$} \\
\hline - Illiterate & 12 & 7 & 8.1 & 5 & 5.8 & & \\
\hline - Read and write & 24 & 19 & 22.1 & 5 & 5.8 & & \\
\hline - Secondary school & 17 & 10 & 11.6 & 7 & 8.1 & & \\
\hline - Technical school & 20 & 10 & 11.6 & 10 & 11.6 & & \\
\hline - University and above & 13 & 7 & 8.1 & 6 & 7.0 & & \\
\hline \multicolumn{6}{|l|}{ Monthly income } & \multirow{3}{*}{2.14} & \multirow{3}{*}{.212} \\
\hline - Enough & 46 & 30 & 34.9 & 16 & 18.6 & & \\
\hline - Not enough & 40 & 23 & 26.7 & 17 & 19.8 & & \\
\hline \multicolumn{6}{|l|}{ Job } & \multirow{6}{*}{3.47} & \multirow{6}{*}{.421} \\
\hline - Governmental sector & 24 & 13 & 15.1 & 11 & 12.8 & & \\
\hline - Private sector & 15 & 8 & 9.3 & 7 & 8.1 & & \\
\hline - Freelancers & 14 & 11 & 12.8 & 3 & 3.5 & & \\
\hline - Crafts & 16 & 9 & 10.5 & 7 & 8.1 & & \\
\hline - Not working & 17 & 12 & 14.0 & 5 & 5.8 & & \\
\hline
\end{tabular}

(*) Statistically significant at p-value $<0.05$.

(**) Highly statistically significant at p-value $<0.05$.

Table (13): shows that there is a statistically significant relation between elderly people total attitude scores and their age, gender, marital status, and 
educational level. While, there is no statistically significant relation between elderly people' total knowledge scores and their monthly income, and job.

Table (14) the relation between elderly people' medical history and their total knowledge scores

\begin{tabular}{|c|c|c|c|c|c|c|c|}
\hline \multirow[t]{2}{*}{ Medical history } & \multirow[t]{2}{*}{$\begin{array}{l}\mathbf{N} \\
\mathbf{0}\end{array}$} & \multicolumn{2}{|c|}{$\begin{array}{l}\text { Inadequate } \\
\text { knowledge }\end{array}$} & \multicolumn{2}{|c|}{$\begin{array}{l}\text { Adequate } \\
\text { knowledge }\end{array}$} & \multirow[t]{2}{*}{$\overline{X^{2}}$} & \multirow[t]{2}{*}{$\begin{array}{c}\text { P- } \\
\text { Value }\end{array}$} \\
\hline & & No & $\%$ & No & $\%$ & & \\
\hline \multicolumn{6}{|c|}{ Number of currently used medications } & \multirow{3}{*}{14.5} & \multirow{3}{*}{$.001 *$} \\
\hline $\begin{array}{r}\text { - Less than } 5 \\
\text { medications }\end{array}$ & 49 & 43 & 50.0 & 6 & 7.0 & & \\
\hline $\begin{array}{r}\text { - More than } 5 \\
\text { medications }\end{array}$ & 37 & 20 & 23.3 & 17 & 19.8 & & \\
\hline \multicolumn{6}{|c|}{$\begin{array}{l}\text { Level of dependency in performing Activity of Daily } \\
\text { Living }\end{array}$} & \multirow{4}{*}{4.85} & \multirow{4}{*}{.079} \\
\hline - Independent & 29 & 23 & 26.7 & 6 & 7.0 & & \\
\hline - partially dependent & 40 & 25 & 29.1 & 15 & 17.4 & & \\
\hline - Totally dependent & 17 & 15 & 17.4 & 2 & 2.3 & & \\
\hline \multicolumn{6}{|l|}{ Current living situation } & \multirow{4}{*}{14.3} & \multirow{4}{*}{$.002 *$} \\
\hline - Home with family & 55 & 34 & 39.5 & 21 & 24.4 & & \\
\hline - Home with caregiver & 26 & 24 & 27.9 & 2 & 2.3 & & \\
\hline - Home independently & 5 & 5 & 5.8 & 0 & 0 & & \\
\hline \multicolumn{6}{|c|}{ Accessibility to medical health services } & \multirow{3}{*}{.325} & \multirow{3}{*}{.122} \\
\hline - Easy to reach & 38 & 29 & 33.7 & 9 & 10.5 & & \\
\hline - Difficult to reach & 48 & 34 & 39.5 & 14 & 16.3 & & \\
\hline
\end{tabular}

(*) Statistically significant at $\mathbf{p}$-value $<0.05$. ${ }^{(* *)}$ Highly statistically significant at $\mathbf{p}$-value $<0.05$.

Table (14): reveals that there is a statistically significant relation between elderly people' total knowledge scores and their number of currently used medications, and current living situation. While, there is no statistically significant relation between elderly people total knowledge scores and their level of dependency in performing activity of daily living, and accessibility to medical health services 
Table (15) :the relation between elderly people' medical history and their total attitude scores

\begin{tabular}{|c|c|c|c|c|c|c|c|}
\hline \multirow[t]{2}{*}{ Medical history } & \multirow[t]{2}{*}{ No } & \multicolumn{2}{|c|}{$\begin{array}{l}\text { Positive } \\
\text { attitude }\end{array}$} & \multicolumn{2}{|c|}{$\begin{array}{l}\text { Negative } \\
\text { attitude }\end{array}$} & \multirow[t]{2}{*}{$\overline{X^{2}}$} & \multirow{2}{*}{$\begin{array}{c}\text { P- } \\
\text { Valu } \\
\text { e }\end{array}$} \\
\hline & & No & $\%$ & No & $\%$ & & \\
\hline \multicolumn{6}{|c|}{ Number of currently used medications } & 1.28 & .172 \\
\hline $\begin{array}{l}\text { - Less than } 5 \\
\text { medications }\end{array}$ & 49 & 30 & 34.9 & 19 & 22.1 & & \\
\hline $\begin{array}{r}\text { - More than } 5 \\
\text { medications }\end{array}$ & 37 & 23 & 26.7 & 14 & 16.3 & & \\
\hline \multicolumn{6}{|c|}{ Level of dependency in performing Activity of Daily Living } & 6.13 & $.042^{*}$ \\
\hline - Independent & 29 & 23 & 26.7 & 6 & 7.0 & & \\
\hline - partially dependent & 40 & 22 & 25.6 & 18 & 20.9 & & \\
\hline - Totally dependent & 17 & 8 & 9.3 & 9 & 10.5 & & \\
\hline \multicolumn{6}{|l|}{ Current living situation } & 7.25 & $.026^{*}$ \\
\hline - Home with family & 55 & 30 & 34.9 & 25 & 29.1 & & \\
\hline - Home with caregiver & 26 & 18 & 20.9 & 8 & 9.3 & & \\
\hline - Home independently & 5 & 5 & 5.8 & 0 & 0 & & \\
\hline \multicolumn{6}{|c|}{ Accessibility to medical health services } & 5.85 & $.014^{*}$ \\
\hline - Easy to reach & 38 & 18 & 20.9 & 20 & 23.3 & & \\
\hline - Difficult to reach & 48 & 35 & 40.7 & 13 & 15.1 & & \\
\hline
\end{tabular}

(*) Statistically significant at p-value $<0.05$. (**) Highly statistically significant at p-value $<0.05$.

Table (15): clarifies that there is a statistically significant relation between elderly people' total attitude scores and their level of dependency in performing activity of daily living, current living situation, and accessibility to medical health services. While, there is no statistically significant relation between elderly people' total knowledge scores and their number of currently used medications

Table (16) Correlation between people' total knowledge and their attitude.

\begin{tabular}{|c|l|c|}
\hline Variables & $\begin{array}{c}\text { Statistical } \\
\text { test }\end{array}$ & Total attitude scores \\
\hline \multirow{2}{*}{ Total knowledge scores } & $\mathrm{r}$ & .578 \\
\cline { 2 - 3 } & $\mathrm{P}$ & $.000 * *$ \\
\hline
\end{tabular}

(**) Highly statistically significant at p-value $<0.05$. 
Table (16): shows that there was a highly positive association between elderly people total knowledge and their total attitude score.

Table (17) distribution of studied elderly people regarding barrier affecting their utilization of assistive devices.

\begin{tabular}{|l|l|c||}
\hline \multicolumn{1}{|c|}{ Barriers } & Frequency & \% \\
\hline Cost & 55 & $64.0 \%$ \\
\hline Technical illiteracy & 71 & $82.6 \%$ \\
\hline Limitations of device & 49 & $57.0 \%$ \\
\hline decrease interaction with caregiver & 53 & $61.6 \%$ \\
\hline Poor sound quality & 69 & $80.2 \%$ \\
\hline Users forget how to use them & 52 & $60.5 \%$ \\
\hline Lack of awareness of availability of AT & 51 & $59.3 \%$ \\
\hline $\begin{array}{l}\text { Limited training regarding utilized assistive } \\
\text { device }\end{array}$ & 60 & $69.8 \%$ \\
\hline Loss of dignity & 49 & $57.0 \%$ \\
\hline Feeling of embarrassment & 48 & $55.8 \%$ \\
\hline Complex interfaces & 59 & $68.6 \%$ \\
\hline Fear of dependency & 49 & $57.0 \%$ \\
\hline
\end{tabular}

Table (17): illustrates that, $82.6 \% \& 80.2 \%$ of the studied elderly people reported that technical illiteracy and poor sound quality of the assistive devices is the barriers that affecting their assistive devices respectively.

\section{DISCUSSION:}

Elderly is defined as the final adult period beginning in the 60 years, Elderly is the phase of decreasing intellect, physical, and psychological ability. The decreased physical condition may include slow body movements, lack of balance of body, decreased coordination of movement between the limbs, decreased memory, and decreased capacity to process information, those limitations make elderly difficulty to do their activity and they start depend on others. Limitations possessed by the elderly can be overcome with the help of assistive devices (17).

Assistive devices benefits older adults by providing them a chance to stay at home safely and besides that it eliminates burden of care givers and nurses (3). In addition, Harrefors et al. (18) confirmed that nurses can have better use of their time to help fully care dependent patients. As a result, there would be better use of time and 
human resource and reduction of healthcare cost.For many patients, independence in a particular situation (transferring, feeding, toileting, etc.) can only be improved through the use of an assistive device (19).

Assistive devices play important role in maintaining physical function, preventing functional decline and enabling older people with disability to cope up with their day to day life routines (20). For older people living with Dementia and other cognitive problems, assistive solutions and environmental modifications have a potential to provide an opportunity to live safely in their own homes without depending fully on caregivers. This also benefits nurses and informal care givers by reducing their burden, Orem highlighted that Nurses have knowledge and skills that can benefit people with declined ability to provide continuous self-care due to health and other physiological conditions. However, people need to maintain their self-case ability as long as possible, in order to regulate their human functioning development (21).

According to elderly personnel characteristics, the results of the current study showed that one half of the studied elderly patients age ranged from $75 \geq 85$ years old, nearly two third of them were male, nearly half of them were widowed. In addition, nearly one third of them could read and write and a low percentage of them had a higher level of education. Furthermore, more than half of them had enough monthly income (Table 1). This finding was in the same line with Navabi et al., (22), in the study to "evaluate Older adults' attitudes and barriers toward the use assistive devices. Also Kamal etal., (2015) in the study to "assess the risk factors of falls among elderly clients at geriatric home", Who added that $21 \%$ of the elderly could read and write and a low parentage of them had a higher level of education. In addition, Hestekin et al. (2013) in the study to "Measure prevalence and risk factors for fall related injury in older adults in low-and middle-income countries, who illustrated that about $25.3 \%$ of participant, had primary school education.

Regarding the medical history of the studied elderly people, the present study findings indicated that the highest percentage of elderly people had a diabetes mellitus, hypertension and asthma. These findings are in accordance with Kamal etal.,( 2015), who added that a high percent of the studied sample were suffering from hypertension, arthritis and diabetes mellitus respectively. In relation to the assistive devices using history among studied elderly people, the present study findings indicated that more than one third of the studied elderly people utilized the 
assistive devices from more than 10 years ago and the majority of them utilized two and three assistive devices.These findings are consistent with a US prevalence study that reported that one-third of mobility device users reported using more than one device and multiple device use may suggest specific needs for each walking aid used according to physical capacity or environmental demands. are agreed with Gell et al., (23).

The concept of self-care includes the ability to care for oneself and the performance of activities necessary to achieve, maintain, or promote optimal health. Different healthcare disciplines share the idea that self-care is conditional and influenced by culture and situations. The effort individuals make towards achieving optimal health depends on individual's capacity and personal characteristics such as amount control over own life, skills, personal values and level of literacy. Selfconcept may be varying from managing health fully independently to relaying completely on medical care Richard et al. (24). Moreover, self-care can contribute for human structural integrity and human development in many ways, if it is executed successfully (25).

There are a several research studies that indicated that application of assistive devices plays important role in maintaining physical and cognitive functioning of the elderly and empowers them to live independently and safely. It also showed that assistive devices contributes a lot in improving quality of life of elderly people living at home and reduce burden of care givers as well as health care cost, As regarding the effect of utilization of assistive device on the Self-care among the studied elderly people. The present study findings revealed that more than half of the studied elderly people reported that utilization of assistive devices is highly positively affected their self-care abilities ( table 5). These findings are agreed with a study to identify that assistive devices products and services such as assistive robots, medication dispensers, telemedicine and sensory technology helped safe medication intake, preventing and detecting falls, minimizing depression and supporting independent living and self-care Khosravi\& Ghapanchi,(3).

Concerning the effect of assistive devices on the quality of life among the studied elderly people the present study findings revealed that nearly half of the studied elderly people reported that assistive devices improve their self-care abilities, physical wellbeing and social wellbeing (table 5). These findings are in accordance 
with Therriault et al., (26) ), who stated that assistive devices had a positive effects on older, independence, psychological well-being, and social status, and the possibilities of negative consequences have been neglected. On the other hand, more than half of elderly people reported that utilizing assistive devices moderately affected their daily activities and emotional wellbeing, these findings are disagreed with Thakur \& Han (27), who reported that assistive devices improve elderly people ability to perform their daily activities and highly affect their psychological wellbeing.

As regarding the studied elderly people knowledge and attitude toward assistive devices, the present study findings indicated that, nearly two third of the studied elderly people had unsatisfactory level of knowledge, these findings may be due to that lack of educational program for elderly people concerning knowledge of the assistive devices. These findings are in accordance with Witte, et al. (28) Who added that elderly people had a barrier of lack of information for utilizing the assistive devices. Moreover, the present study findings indicated that nearly two third of the studied elderly people had a negative attitude regarding their assistive devices, this may be due to the lack of knowledge and lack of training for using and maintaining of their assistive devices. These results are in accordance with Sisay (3), who added that The elderly people had negative attitude regarding their assistive devices

\section{Conclusion:}

Based on the result of the present study it was concluded that, nearly three quarter of the studied elderly people had unsatisfactory level of knowledge regarding assistive devices, nearly two third of the studied elderly had a negative attitude. In addition, there was a highly positive association between elderly people total knowledge and their total attitude score regarding the assistive devices. Moreover, the majority of the studied elderly people indicated that technical literacy and poor sound quality of the assistive devices is the barriers that affecting their assistive devices respectively. 


\section{Recommendation}

In the light of the results of the present study, the following recommendations were suggested:

Developing an educational program for the elderly people aiming at raising their awareness and knowledge about the utilized assistive devices.

Caregiver should be included during orientation of elderly people regarding using of assistive devices.

Further studies should be conducted in different settings.

Assessment of assistive devices on elderly people on their quality of life and daily activity.

\section{DISCLOSURES}

Ethical clearance: taken from ethical research committee, faculty of nursing BeniSuef University, Egypt.

Conflict of interest: No conflict of interest. Source of Funding: self-Funding

Data Availability: The authors confirm that all data underlying the findings are fully available without restriction. All relevant data are within the paper and its Supporting Information files.

\section{References:}

1. Sharmila, K. (2020). Role of happiness in health of elderly. Indian Journal of Gerontology, 34(4), 544-552.

2. Skalska, A., Wizner, B., Piotrowicz, K., Klich-Rączka, A., Klimek, E., Mossakowska, M., ... \& Grodzicki, T. (2013). The prevalence of falls and their relation to visual and hearing impairments among a nation-wide cohort of older Poles. Experimental gerontology, 48(2), 140-146.

3. Sisay, M. (2017). The use of assistive devices to support self care of the elderly people at home. 
4. Prajapati, G., \& Sharmila, K. (2021). A Pilot Study on Assistive Device usage and Mental Wellbeing of Elderly. Annals of the Romanian Society for Cell Biology, 25(6), 13144-13154.

5. Carmeli, E., Imam, B., \& Merrick, J. (2016). Assistive technology and older adults. In Health care for people with intellectual and developmental disabilities across the lifespan (pp. 1465-1471). Springer, Cham.

6. Tangcharoensathien, V., Witthayapipopsakul, W., Viriyathorn, S., \& Patcharanarumol, W. (2018). Improving access to assistive technologies: challenges and solutions in low-and middle-income countries. WHO South-East Asia journal of public health, 7(2), 84.

7. Freedman, V. A., Kasper, J. D., Cornman, J. C., Agree, E. M., Bandeen-Roche, K., Mor, V., ... \& Wolf, D. A. (2011). Validation of new measures of disability and functioning in the National Health and Aging Trends Study. Journals of Gerontology Series A: Biomedical Sciences and Medical Sciences, 66(9), 1013-1021.

8. Shweta, S., Rajib, D., Ravinder, S., \& Sharma, S. (2019). "Equipping, empowering, enabling": Centre-staging assistive technologies in disability and rehabilitation policy discourse in India. Global perspectives on assistive technology, 418.

9. Halvorsrud, L., Holthe, T., Karterud, D., Thorstensen, E., \& Lund, A. (2021). Perspectives on assistive technology among older Norwegian adults receiving community health services. Disability and Rehabilitation: Assistive Technology, 1-8.

10. Siegel, C., \& Dorner, T. E. (2017). Information technologies for active and assisted living —Influences to the quality of life of an ageing society. International journal of medical informatics, 100, 32-45.

11. Arman, M., \& Hök, J. (2016). Self-care follows from compassionate care-chronic pain patients' experience of integrative rehabilitation. Scandinavian journal of caring sciences, 30(2), 374-381.

12. Dionne-Odom, J. N., Demark-Wahnefried, W., Taylor, R. A., Rocque, G. B., Azuero, A., Acemgil, A., ... \& Bakitas, M. A. (2017). The self-care practices of family caregivers of persons with poor prognosis cancer: differences by varying levels of caregiver well-being and preparedness. Supportive Care in Cancer, 25(8), 2437-2444.

13. Sabo, K., \& Chin, E. (2021). Self-care needs and practices for the older adult caregiver: An integrative review. Geriatric Nursing, 42(2), 570-581.

14. Bourne, R., Steinmetz, J. D., Flaxman, S., Briant, P. S., Taylor, H. R., Resnikoff, S., ... \& Tareque, M. I. (2021). Trends in prevalence of blindness and distance and near vision impairment over 30 years: an analysis for the Global Burden of Disease Study. The Lancet Global Health, 9(2), e130e143.

15. Häggblom-Kronlöf, G., \& Sonn, U. (2007). Use of assistive devices-a reality full of contradictions in elderly persons' everyday life. Disability and Rehabilitation: Assistive Technology, 2(6), 335-345.

16. Lin, I. F., \& Wu, H. S. (2014). Activity limitations, use of assistive devices or personal help, and wellbeing: Variation by education. Journals of Gerontology Series B: Psychological Sciences and Social Sciences, 69(Suppl_1), S16-S25.

17. Akbar, M. F., \& Putri, R. A. (2018). Assistive and wearable technology for elderly. Bulletin of Social Informatics Theory and Application, 2(1), 8-14. 
18. Axelsson, K., Harrefors, C., Sävenstedt, S., \& Wälivaara, B. M. (2010). E-Health in care of older persons in the future. In Journal of Clinical Nursing (Vol. 19, No. Suppl. 1, p. 54).

19. Pereira, E. P. R., Cavalcanti, R. N., Esmerino, E. A., Silva, R., Guerreiro, L. R. M., Cunha, R. L., ... \& Cruz, A. G. (2016). Effect of incorporation of antioxidants on the chemical, rheological, and sensory properties of probiotic petit suisse cheese. Journal of Dairy Science, 99(3), 1762-1772.

20. Andrich, R., Mathiassen, N. E., Hoogerwerf, E. J., \& Gelderblom, G. J. (2013). Service delivery systems for assistive technology in Europe: An AAATE/EASTIN position paper. Technology and Disability, 25(3), 127-146.

21. Kerssens, C., Kumar, R., Adams, A. E., Knott, C. C., Matalenas, L., Sanford, J. A., \& Rogers, W. A. (2015). Personalized technology to support older adults with and without cognitive impairment living at home. American Journal of Alzheimer's Disease \& Other Dementias ${ }^{\circledR}, 30(1), 85-97$.

22. Navabi, N., Ghaffari, F., \& Jannat-Alipoor, Z. (2016). Older adults' attitudes and barriers toward the use of mobile phones. Clinical interventions in aging, 11, 1371.

23. Gell, N. M., Rosenberg, D. E., Demiris, G., LaCroix, A. Z., \& Patel, K. V. (2015). Patterns of technology use among older adults with and without disabilities. The Gerontologist, 55(3), 412-421.

24. Richard, L., Gauvin, L., \& Raine, K. (2011). Ecological models revisited: their uses and evolution in health promotion over two decades. Annual review of public health, 32, 307326.

25. Söderhamn, U., Dale, B., \& Söderhamn, O. (2013). The meaning of actualization of selfcare resources among a group of older home-dwelling people-A hermeneutic study. International journal of qualitative studies on health and well-being, 8(1), 20592.

26. Pascoal, T. A., Shin, M., Kang, M. S., Chamoun, M., Chartrand, D., Mathotaarachchi, S., ... \& Rosa-Neto, P. (2018). In vivo quantification of neurofibrillary tangles with [18 F] MK6240. Alzheimer's research \& therapy, 10(1), 1-14.

27. Thakur, N., \& Han, C. Y. (2019). Framework for a personalized intelligent assistant to elderly people for activities of daily living. Int. J. Recent Trends Hum. Comput. Interact.(IJHCI), 9(1), 1-22.

28. Mahajan, A., Taliun, D., Thurner, M., Robertson, N. R., Torres, J. M., Rayner, N. W., ... \& McCarthy, M. I. (2018). Fine-mapping type 2 diabetes loci to single-variant resolution using high-density imputation and islet-specific epigenome maps. Nature genetics, 50(11), 15051513. 